\title{
MORPHOAGRONOMIC CHARACTERIZATION OF Lantana camara L. GERMPLASM
}

\author{
CARACTERIZAÇÃO MORFOAGRONÔMICA DE GERMOPLASMA DE Lantana \\ camara $L$.
}

\author{
Luís Fernando de Andrade NASCIMENTO'; ${ }^{1}$ Arie Fitzgerald BLANK²; \\ José Carlos Freitas de SÁ FILHO'; Katily Luize Garcia PEREIRA³; \\ Daniela Aparecida de Castro NIZIO ${ }^{4}$; Maria de Fátima ARRIGONI-BLANK²; \\ Alisson Marcel Souza de OLIVEIRA ${ }^{5}$; Vinícius Trindade de SOUZA ${ }^{6}$
}

\begin{abstract}
1. Mestrando em Agricultura e Biodiversidade, Universidade Federal de Sergipe-UFS, São Cristovão, SE, Brasil; 2. Professor, Doutor, Departamento de Engenharia Agronômica, UFS, São Cristóvão, SE, Brasil. arie.blank@gmail.com ; 3. Doutora em Ciências, UFS, São Cristovão, SE, Brasil; 4. Doutora em Biotecnologia, UFS, São Cristovão, SE, Brasil; 5. Professor, Doutor, Campus do Sertão, UFS, Nossa Senhora da Glória, SE, Brasil; 6. Graduando em Agronomia, Departamento de Engenharia Agronômica, UFS, São Cristóvão, SE, Brasil
\end{abstract}

\begin{abstract}
The medicinal and aromatic species Lantana camara is a bush that receives a lot of interest regarding ornamental use. However, due to its condition of invasive plant in natural environments, it suffers constant eradication attempts, which causes genetic erosion of the species. To work around this problem, a sample of the genetic variability of L. camara was saved in the Active Germplasm Bank of medicinal and aromatic plants of the Federal University of Sergipe (UFS). This study aimed to evaluate morphoagronomically 22 accessions of $L$. camara, collected in 15 municipalities in the state of Sergipe. To carry out morphoagronomic characterization, morphological and agronomic traits were analyzed. Phenotypic variability among the accessions of the L. camara collection for all the analyzed morphological quantitative and agronomic characteristics was observed. The means ranged from 4.91 to $6.90 \mathrm{~cm}$ for leaf length; from 2.81 to $5.03 \mathrm{~cm}$ for leaf width; from 1.32 to 1.87 for the leaf length/width ratio; from 9.59 to $22.98 \mathrm{~mm}^{2}$ for leaf area; from 99.00 to $215.00 \mathrm{~cm}$ for crown diameter; from 85.67 to 214.33 for plant height; and from 1.08 to $2.43 \mathrm{~cm}$ for stem diameter. Most accessions presented erect form. The mean number of flowers per inflorescence varied from 12 to 38 flowers. For the agronomic traits, we observed that the dry mass ranged from 49.86 to 649.04 g.plant ${ }^{-1}$. The mean content of essential oil ranged from 0.13 to $0.26 \%$ and yield between 0.10 and 1.55

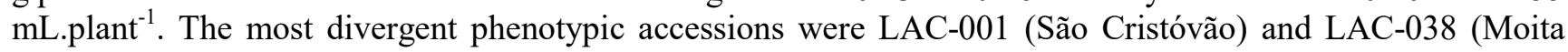
Bonita) and the ones with the lowest divergence were LAC-004 (Itaporanga D'ajuda) and LAC-019 (Siriri). Thus, it was observed that the variables were efficient to differentiate the accessions and suggest the existence of genetic variability among them.
\end{abstract} Diversity.

KEYWORDS: Verbenaceae. Medicinal and aromatic plant. Active Germplasm Bank. Descriptors.

\section{INTRODUCTION}

Lantana camara L. (Verbenaceae), popularly known in Brazil as cambará or chumbinho, is a bush with branched stem, intertwined twigs, and multicolored inflorescences. Native to tropical and subtropical America, it was soon introduced in several countries, in which it can be considered both as an invasive plant and an ornamental species (GHISALBERTI, 2000; DOS SANTOS et al., 2019). In natural environments, it is an aggressive biological invader that competes with other native species and, therefore, is subject to biological, physical and chemical eradication attempts, which consequently causes genetic erosion of the species (PRASAD; RATMAN; SANKARAN, 2018). On the other hand, when properly subjected to genetic improvement, it presents high ornamental value to the floriculture industry, in many parts of the world, since it blooms throughout the year, attracts numerous species of pollinators, tolerates adverse environmental conditions, and has low maintenance requirements (DENG et al., 2017).

In addition to its importance as an ornamental plant, L. camara is an important medicinal and aromatic species. It is used in folk medicine for the treatment of ulcers, cataracts, colds, asthma, chickenpox, bronchitis, rheumatism, among others. Scientific studies support its antibacterial, antifungal, anti-oxidant, antipyretic, insecticide, antimicrobial, and healing action (JAGTAP et al., 2018; VED et al., 2018). Its therapeutic properties are linked to the chemical 
Morphoagronomic characterization...

profile of its extracts (SOUSA et al., 2013) and essential oils found in the leaves (DOS SANTOS et al., 2019), flowers (SANTOS et al., 2015), and stem (MEDEIROS et al., 2012). Essential oils are a complex mixture of volatile molecules with large variation in their composition. They can be used in the synthesis of various products (NIZIO et al., 2018).

Given the vast importance of this species and the imminent loss of important genotypes, the Federal University of Sergipe (UFS) has established a collection of $L$. cambara in the Active Germplasm Bank of medicinal and aromatic plants. Thus, the genetic material is kept in the field in which a sample of the genetic variability of the species present in the state of Sergipe is conserved. After the conservation of a species in BAG, characterization studies are needed to establish interesting traits for a genetic improvement program (BLANK, 2013). These studies can be carried out through genetic and phenotypic markers. Phenotypic markers allow us to know the morphological, agronomic and chemical aspects of a species, while molecular markers are tools used to directly access polymorphism in DNA.

Morphoagronomic markers are more accessible than molecular markers and have been used in several phenotypic characterization studies of germplasm (ALVES et al., 2017; BIANCHINI et al., 2017; SILVA et al., 2017; SANTANA et al.,
NASCIMENTO, L. F. A. et al.

2018) with the goal of increasing the number of information about the collection, in addition to providing data related to the cultivation, production, and use of the species (JANSKY; DAWSON; SPOONER, 2015).

Before starting a genetic improvement program, it is essential that divergent morphoagronomic characteristics among the accessions are triaged. This shall define the selection and conservation criteria as well as improvement strategies. In this sense, this study aimed to evaluate morphoagronomically the collection of L. camara maintained in the Active Germplasm Bank of medicinal and aromatic plants of the Federal University of Sergipe.

\section{MATERIAL AND METHODS}

\section{Plant material}

Twenty-two accessions of $L$. camara preserved in the Active Germplasm Bank of medicinal and aromatic plants of the Federal University of Sergipe (UFS), located at the Experimental Farm "Campus Rural da UFS", municipality of São Cristóvão, Brazil ( $11^{\circ} 00^{\prime} \mathrm{S}$, $\left.37^{\circ} 12^{\prime} \mathrm{W}\right)$, were characterized. The exsiccatae of all accessions were deposited at the Herbarium of the UFS (ASE), which were registered and identified with a voucher number (Table 1).

Table 1. Identification of the places of origin of the 22 accessions of the Lantana camara collection of the Active Germplasm Bank of medicinal and aromatic plants of the Federal University of Sergipe.

\begin{tabular}{|c|c|c|c|}
\hline Accessions & Origin (Municipality), Sergipe, Brasil & Voucher number & Georreferenciamento \\
\hline LAC-001 & São Cristóvão & $37068-1$ & $10^{\circ} 55^{\prime} 27,3^{\prime \prime} \mathrm{S} ; 37^{\circ} 11^{\prime} 56,9^{\prime \prime} \mathrm{W}$ \\
\hline LAC-002 & São Cristóvão & $37068-2$ & $10^{\circ} 55^{\prime} 22,8^{\prime \prime} \mathrm{S} ; 37^{\circ} 11^{\prime} 59,0^{\prime \prime} \mathrm{W}$ \\
\hline LAC-003 & Itaporanga D'Ajuda & $36313-1$ & $11^{\circ} 01^{\prime} 33,5^{\prime \prime} \mathrm{S} ; 37^{\circ} 19^{\prime} 40,9^{\prime \prime} \mathrm{W}$ \\
\hline LAC-004 & Itaporanga D'Ajuda & $36313-2$ & $11^{\circ} 01^{\prime} 32,1^{\prime \prime S} ; 37^{\circ} 19^{\prime} 40,5^{\prime \prime} \mathrm{W}$ \\
\hline LAC-007 & Malhada dos Bois & $36322-1$ & $10^{\circ} 21^{\prime} 40,3^{\prime \prime} \mathrm{S} ; 36^{\circ} 54^{\prime} 28,3^{\prime \prime} \mathrm{W}$ \\
\hline LAC-011 & Maruim & $36333-1$ & $10^{\circ} 44^{\prime} 02,2^{\prime \prime} \mathrm{S} ; 37^{\circ} 05^{\prime} 10,6^{\prime \prime} \mathrm{W}$ \\
\hline LAC-012 & Maruim & $36333-2$ & $10^{\circ} 43^{\prime} 59,7^{\prime \prime} \mathrm{S} ; 37^{\circ} 05^{\prime} 08,2^{\prime \prime} \mathrm{W}$ \\
\hline LAC-013 & Nossa Senhora das Dores & $36634-1$ & $10^{\circ} 31^{\prime} 29,0^{\prime \prime} \mathrm{S} ; 37^{\circ} 15^{\prime} 00,3^{\prime \prime} \mathrm{W}$ \\
\hline LAC-016 & Riachuelo & $36643-1$ & $10^{\circ} 44^{\prime} 10,0^{\prime \prime} \mathrm{S} ; 37^{\circ} 11^{\prime} 03,3^{\prime \prime} \mathrm{W}$ \\
\hline LAC-017 & Divina Pastora & $36645-1$ & $10^{\circ} 41^{\prime} 14,6^{\prime \prime} \mathrm{S} ; 37^{\circ} 09^{\prime} 59,8^{\prime \prime} \mathrm{W}$ \\
\hline LAC-018 & Divina Pastora & $36645-2$ & $10^{\circ} 41^{\prime} 15,5^{\prime \prime} \mathrm{S} ; 37^{\circ} 10^{\prime} 03,3^{\prime \prime} \mathrm{W}$ \\
\hline LAC-019 & Siriri & $36651-1$ & $10^{\circ} 37^{\prime} 08,5^{\prime \prime} \mathrm{S} ; 37^{\circ} 05^{\prime} 38,2^{\prime \prime} \mathrm{W}$ \\
\hline LAC-021 & Salgado & $36888-1$ & $11^{\circ} 01^{\prime} 29,2^{\prime \prime} \mathrm{S} ; 37^{\circ} 25^{\prime} 25,4^{\prime \prime} \mathrm{W}$ \\
\hline LAC-025 & Riachão do Dantas & $36898-1$ & $11^{\circ} 01^{\prime} 15,2^{\prime \prime} \mathrm{S} ; 37^{\circ} 43^{\prime} 17,2^{\prime \prime} \mathrm{W}$ \\
\hline LAC-027 & Japaratuba & $36903-1$ & $10^{\circ} 35^{\prime} 09,5^{\prime \prime} \mathrm{S} ; 36^{\circ} 57^{\prime} 46,3^{\prime \prime} \mathrm{W}$ \\
\hline LAC-028 & Japaratuba & $36903-2$ & $10^{\circ} 35^{\prime} 07,5^{\prime \prime} \mathrm{S} ; 36^{\circ} 58^{\prime} 00,8^{\prime \prime} \mathrm{W}$ \\
\hline LAC-034 & Areia Branca & $38262-2$ & $10^{\circ} 46^{\prime} 10,6^{\prime \prime} \mathrm{S} ; 37^{\circ} 22^{\prime} 02,9^{\prime \prime} \mathrm{W}$ \\
\hline LAC-035 & Itabaiana & $38265-1$ & $10^{\circ} 44^{\prime} 54,4^{\prime \prime} \mathrm{S} ; 37^{\circ} 23^{\prime} 55,9^{\prime \prime} \mathrm{W}$ \\
\hline LAC-036 & Itabaiana & $38265-2$ & $10^{\circ} 44^{\prime} 15,3^{\prime \prime S} ; 37^{\circ} 24^{\prime} 24,2^{\prime \prime} \mathrm{W}$ \\
\hline LAC-037 & Moita Bonita & $38273-1$ & $10^{\circ} 36^{\prime} 19,4^{\prime \prime} \mathrm{S} ; 37^{\circ} 21^{\prime} 13,6^{\prime \prime} \mathrm{W}$ \\
\hline LAC-038 & Moita Bonita & $38273-2$ & $10^{\circ} 35^{\prime} 40,6^{\prime \prime} \mathrm{S} ; 37^{\circ} 20^{\prime} 56,3^{\prime \prime} \mathrm{W}$ \\
\hline LAC-040 & Ribeirópolis & $38278-2$ & $10^{\circ} 33^{\prime} 27,6^{\prime \prime} \mathrm{S} ; 37^{\circ} 22^{\prime} 34,5^{\prime \prime} \mathrm{W}$ \\
\hline
\end{tabular}


Vegetative parts from 22 naturally occurring plants were collected in different municipalities of the state of Sergipe, Brazil (Table 1), in highly anthropized locations. L. camara cuttings were rooted in $280-\mathrm{cm}^{3}$ tubes filled with substrate in a $3: 1$ ratio of soil of the experimental farm of the UFS and tanned cattle manure, respectively. The plants were kept in a greenhouse, with irrigation distributed in five periods of 3 minutes during the day.

Before preparation of the substrate, soil samples from the experimental farm of the UFS were collected from the $0-20 \mathrm{~cm}$ layer for physicochemical analyses: $\mathrm{pH}$ (water) $=5.03$; organic matter $=13.2 \mathrm{~g} / \mathrm{dm}^{3} ; \mathrm{Al}^{+}{ }^{3}=0.47$ $\mathrm{cmol} / \mathrm{DM}^{3} ; \mathrm{K}=31.2 \mathrm{mg} / \mathrm{dm}^{3} ; \mathrm{P}=3.10 \mathrm{mg} / \mathrm{dm}^{3}$; CTC $3.63 \mathrm{cmol} / \mathrm{dm}^{3}$.

The seedlings were placed in the field in June 2016, when they were already "hardened". The collection was deployed in randomized blocks design with three repetitions. Each division consisted of three plants with spacing of $1 \mathrm{~m}$ between plants, $1 \mathrm{~m}$ between rows, and $2 \mathrm{~m}$ between blocks. The crop procedures consisted of clearing off the field, drip irrigation twice a day (morning and afternoon), and fertilization every three months, with application of $5 \mathrm{~L}$ of tanned cattle manure per plant. The morphological and agronomic characterization were carried out in August 2017.

\section{Morphoagronomic characterization}

For the morphological characterization, we used the descriptors cited by Camêlo et al. (2011) for the Lippia alba species, and by Egata, Geja and Mengesha (2017) for Ocimum basilicum. Specific descriptors such as the presence of thorns in the stems and number of flowers in the inflorescences were included.

The following quantitative morphological variables were analyzed: leaf length (LL), leaf width $(\mathrm{LW})$, leaf length/width ratio (L/W), leaf area (LA); crown diameter $(\mathrm{DCr})$; plant height $(\mathrm{PH})$, stem diameter (DSt), growth habit (GH) (Table 2); number of flowers per inflorescence (NFI); and color of the leaves (CL). To evaluate leaf coloration, four leafs of each plant were digitized on the upper (adaxial) and lower (abaxial) surface, by a HP MFP 1005 scanner. The colors of the leaf blades were analyzed with aid of the Paint software for Windows. Six points of the RGB coloring were sampled on each side of the leaves and their mean values were calculated (Figure 1). To convert the mean RGB color values into the hexadecimal code for international color standardization, we used the WebCalc website (webcalc.com.br);

Table 2. Scale of scores for L. camara plant growth habit.

\begin{tabular}{ll}
\hline Score & Characteristic \\
\hline 1 & Upright plants; no branches touching the ground \\
2 & Plants with $25 \%$ of the branches touching the ground \\
3 & Plants with $50 \%$ of the branches touching the ground \\
4 & Plants with $75 \%$ of the branches touching the ground \\
5 & Plants with $100 \%$ of the branches touching the ground (Decumbent plants) \\
\hline
\end{tabular}

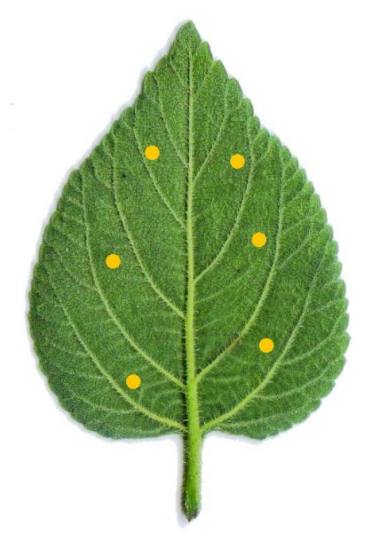

- Sampled points

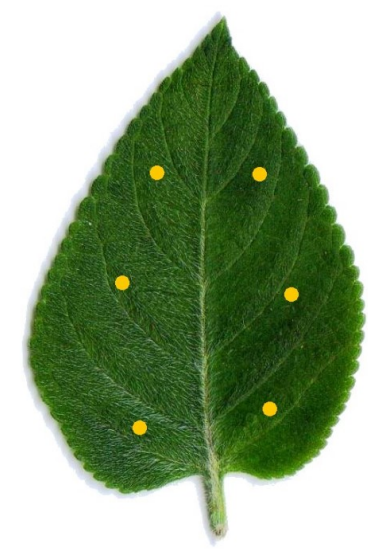

$2 \mathrm{~cm}$

Figure 1. Distribuition of points sampled on Lantana camara leafs. 
The qualitative morphological variables analyzed were: color of the inflorescences (CI) and presence of thorns (PT).

For the agronomic characterization, we collected the maximum possible number of leaves of all plants, to ensure the survival of the plants in the collection.

The collected leaves were kept for five days in an oven with forced air flow and temperature set at $40{ }^{\circ} \mathrm{C} \pm 1$ for drying. The following characteristics were assessed: dry mass of leaves and content and yield of the essential oil. After the hydrodistillation $(75 \mathrm{~g}$ of dried leaves; $1.5 \mathrm{~L}$ of distilled water; $90 \mathrm{~min}$ ) in a modified Clevenger device, the following calculations were performed for the variables content and yield of essential oil:

Content $(\%)=\left(\frac{\text { volume of essential oil extracted from the sample }}{\text { mass dryweight of the sample }}\right) \times 100$

Yield $=\left(\frac{\text { Content }(\%) \times \text { mass dryweight per plant }}{100}\right)$

\section{Statistical analysis}

The data obtained from the morphological and agronomical characterizations were submitted to analysis of variance (ANAVA), and the means were grouped by Scott-Knott test $(p \leq 0.05)$, by the SISVAR ${ }^{\circledR}$ software. Two multivariate analyses were conducted: principal component analysis (PCA) and cluster analysis, using the Statistica ${ }^{\circledR}$ software. For the cluster analysis, a dissimilarity matrix was built based on the morphoagronomic traits, according to the Euclidean distance. The dissimilarity matrix was simplified through a dendrogram using Ward's clustering method.

\section{RESULTS AND DISCUSSION}

According to the analysis of variance, there was a significant difference $(p<0.05)$ among the accessions from the L. camara collection to all qualitative morphologic characteristics (Table 3).

Table 3. Mean values of leaf length (LL), leaf width (LW), leaf length/width ratio (LL/LW), leaf area (LA), crown diameter $(\mathrm{CD})$, plant height $(\mathrm{PH})$, stem diameter $(\mathrm{SD})$, growth habit $(\mathrm{GH})$, and number of flowers per inflorescence (NFI) of the Lantana camara accessions from the Active Germplasm Bank of medicinal and aromatic plants of the Federal University of Sergipe.

\begin{tabular}{|c|c|c|c|c|c|c|c|c|c|c|c|c|c|c|c|c|c|c|}
\hline Acesso & $\begin{array}{l}\mathbf{L L} \\
(\mathbf{c m})\end{array}$ & & $\begin{array}{l}\mathbf{L W} \\
(\mathrm{cm})\end{array}$ & & $\mathbf{L L} / \mathbf{I}$ & & $\begin{array}{l}\mathbf{L A} \\
\left(\mathbf{m m}^{2}\right)\end{array}$ & & $\begin{array}{l}\text { CD } \\
(\mathbf{c m})\end{array}$ & & $\begin{array}{l}\text { PH } \\
(\mathrm{cm})\end{array}$ & & $\begin{array}{l}\text { SD } \\
(\mathrm{cm})\end{array}$ & & GH & & NFI & \\
\hline LAC-001 & 6.34 & $\mathrm{a}$ & 4.76 & $\mathrm{a}$ & 1.34 & $d$ & 20.76 & $\mathrm{a}$ & 131.33 & $\mathrm{~b}$ & 130.67 & $\mathrm{c}$ & 1.47 & $\mathrm{~b}$ & 2.00 & $\mathrm{a}$ & 14.67 & $\mathrm{~d}$ \\
\hline LAC-002 & 5.55 & $\mathrm{~b}$ & 4.17 & $\mathrm{~b}$ & 1.33 & d & 15.57 & $\mathrm{~b}$ & 130.00 & $\mathrm{~b}$ & 130.33 & $\mathrm{c}$ & 1.73 & $\mathrm{~b}$ & 1.33 & $\mathrm{~b}$ & 20.00 & $\mathrm{c}$ \\
\hline LAC-003 & 6.61 & $\mathrm{a}$ & 4.08 & $\mathrm{~b}$ & 1.62 & $\mathrm{~b}$ & 18.76 & $\mathrm{a}$ & 141.67 & $\mathrm{~b}$ & 85.67 & $\mathrm{c}$ & 1.80 & $\mathrm{~b}$ & 2.00 & $\mathrm{a}$ & 19.00 & $\mathrm{c}$ \\
\hline LAC-004 & 6.49 & $\mathrm{a}$ & 4.12 & $\mathrm{~b}$ & 1.58 & $\mathrm{~b}$ & 18.33 & $\mathrm{a}$ & 153.33 & $\mathrm{~b}$ & 125.33 & $\mathrm{c}$ & 1.67 & $\mathrm{~b}$ & 2.00 & $\mathrm{a}$ & 17.00 & $\mathrm{c}$ \\
\hline LAC-007 & 5.45 & $\mathrm{~b}$ & 3.37 & $\mathrm{c}$ & 1.64 & $\mathrm{~b}$ & 12.84 & $\mathrm{~b}$ & 127.00 & $\mathrm{~b}$ & 114.00 & $\mathrm{c}$ & 1.50 & $\mathrm{~b}$ & 2.33 & $\mathrm{a}$ & 28.00 & $\mathrm{~b}$ \\
\hline LAC-011 & 6.34 & $\mathrm{a}$ & 3.68 & $\mathrm{c}$ & 1.73 & $\mathrm{a}$ & 14.45 & $\mathrm{~b}$ & 164.67 & $\mathrm{a}$ & 115.67 & $\mathrm{c}$ & 2.00 & $\mathrm{a}$ & 2.00 & $\mathrm{a}$ & 21.00 & $\mathrm{c}$ \\
\hline LAC-012 & 4.91 & $\mathrm{~b}$ & 2.81 & $\mathrm{c}$ & 1.74 & $\mathrm{a}$ & 9.59 & $\mathrm{~b}$ & 158.67 & $\mathrm{~b}$ & 136.00 & $\mathrm{c}$ & 1.80 & $\mathrm{~b}$ & 2.00 & $\mathrm{a}$ & 17.33 & $\mathrm{c}$ \\
\hline LAC-013 & 5.98 & $\mathrm{a}$ & 3.89 & $\mathrm{~b}$ & 1.53 & $\mathrm{c}$ & 16.65 & $\mathrm{~b}$ & 138.33 & $\mathrm{~b}$ & 150.33 & $b$ & 2.07 & $\mathrm{a}$ & 1.33 & $\mathrm{~b}$ & 17.67 & $\mathrm{c}$ \\
\hline LAC-016 & 6.47 & $\mathrm{a}$ & 4.64 & $\mathrm{a}$ & 1.40 & $\mathrm{~d}$ & 20.46 & $\mathrm{a}$ & 132.50 & $\mathrm{~b}$ & 117.50 & $\mathrm{c}$ & 1.70 & $\mathrm{~b}$ & 2.00 & $\mathrm{a}$ & 14.33 & $\mathrm{~d}$ \\
\hline LAC-017 & 6.57 & $\mathrm{a}$ & 3.99 & $\mathrm{~b}$ & 1.67 & $\mathrm{~b}$ & 18.35 & $\mathrm{a}$ & 99.00 & $\mathrm{~b}$ & 120.00 & $\mathrm{c}$ & 1.65 & $\mathrm{~b}$ & 2.00 & $\mathrm{a}$ & 24.00 & $\mathrm{~b}$ \\
\hline LAC-018 & 6.38 & $\mathrm{a}$ & 4.05 & $\mathrm{~b}$ & 1.59 & $\mathrm{~b}$ & 18.74 & $\mathrm{a}$ & 200.00 & $\mathrm{a}$ & 165.00 & $\mathrm{~b}$ & 2.10 & $\mathrm{a}$ & 2.00 & $\mathrm{a}$ & 28.67 & $\mathrm{~b}$ \\
\hline LAC-019 & 5.99 & $\mathrm{a}$ & 3.62 & $\mathrm{c}$ & 1.65 & $\mathrm{~b}$ & 17.03 & b & 152.00 & b & 143.67 & $\mathrm{~b}$ & 2.33 & $\mathrm{a}$ & 2.00 & $\mathrm{a}$ & 25.00 & $\mathrm{~b}$ \\
\hline LAC-021 & 6.21 & $\mathrm{a}$ & 4.32 & $\mathrm{~b}$ & 1.43 & d & 20.12 & $\mathrm{a}$ & 119.00 & b & 143.50 & $\mathrm{~b}$ & 2.15 & $\mathrm{a}$ & 2.00 & $\mathrm{a}$ & 14.00 & $\mathrm{~d}$ \\
\hline LAC-025 & 6.62 & $\mathrm{a}$ & 5.03 & $\mathrm{a}$ & 1.32 & d & 22.90 & $\mathrm{a}$ & 119.00 & $\mathrm{~b}$ & 132.00 & $\mathrm{c}$ & 1.60 & $\mathrm{~b}$ & 1.67 & $\mathrm{~b}$ & 17.00 & $\mathrm{c}$ \\
\hline LAC- 027 & 6.74 & $\mathrm{a}$ & 3.92 & $b$ & 1.73 & $\mathrm{a}$ & 16.90 & $b$ & 140.67 & $b$ & 138.00 & $\mathrm{c}$ & 2.10 & $\mathrm{a}$ & 2.00 & $\mathrm{a}$ & 38.00 & $\mathrm{a}$ \\
\hline LAC-028 & 5.33 & $\mathrm{~b}$ & 3.99 & $\mathrm{~b}$ & 1.34 & $\mathrm{~d}$ & 15.21 & $\mathrm{~b}$ & 131.67 & $\mathrm{~b}$ & 130.33 & $\mathrm{c}$ & 1.93 & $\mathrm{a}$ & 1.67 & $\mathrm{~b}$ & 12.00 & d \\
\hline LAC-034 & 6.75 & $\mathrm{a}$ & 4.83 & $\mathrm{a}$ & 1.40 & $\mathrm{~d}$ & 22.98 & $\mathrm{a}$ & 156.00 & $\mathrm{~b}$ & 153.67 & $\mathrm{~b}$ & 1.80 & $\mathrm{~b}$ & 2.00 & $\mathrm{a}$ & 26.33 & $\mathrm{~b}$ \\
\hline LAC-035 & 6.13 & $\mathrm{a}$ & 4.04 & $\mathrm{~b}$ & 1.53 & $\mathrm{c}$ & 16.52 & b & 186.00 & $\mathrm{a}$ & 125.67 & $\mathrm{c}$ & 2.43 & $\mathrm{a}$ & 2.00 & $\mathrm{a}$ & 16.33 & $\mathrm{c}$ \\
\hline LAC-036 & 6.90 & $\mathrm{a}$ & 4.21 & $\mathrm{~b}$ & 1.65 & $\mathrm{~b}$ & 21.76 & $\mathrm{a}$ & 146.67 & $\mathrm{~b}$ & 148.33 & $\mathrm{~b}$ & 1.93 & $\mathrm{a}$ & 1.67 & $\mathrm{~b}$ & 15.00 & $\mathrm{~d}$ \\
\hline LAC-037 & 6.33 & $\mathrm{a}$ & 3.81 & $\mathrm{c}$ & 1.67 & $\mathrm{~b}$ & 16.41 & b & 215.00 & $a$ & 214.33 & $\mathrm{a}$ & 2.15 & $\mathrm{a}$ & 2.00 & $a$ & 26.00 & $\mathrm{~b}$ \\
\hline LAC-038 & 6.13 & $\mathrm{a}$ & 3.28 & $\mathrm{c}$ & 1.87 & $\mathrm{a}$ & 14.12 & b & 179.67 & $a$ & 156.00 & $\mathrm{~b}$ & 2.20 & $\mathrm{a}$ & 2.00 & $\mathrm{a}$ & 29.00 & $\mathrm{~b}$ \\
\hline LAC-040 & 6.04 & $\mathrm{a}$ & 3.41 & $\mathrm{c}$ & 1.82 & $\mathrm{a}$ & 13.87 & $\mathrm{~b}$ & 112.06 & $\mathrm{~b}$ & 130.06 & $\mathrm{c}$ & 1.08 & $\mathrm{~b}$ & 2.00 & $a$ & 26.33 & $\mathrm{~b}$ \\
\hline CV (\%) & 10.01 & & 8.91 & & 5.49 & & 16.35 & & 21.27 & & 12.26 & & 16.25 & & 15.98 & & 9.99 & \\
\hline
\end{tabular}

Means followed by the same letter in the column do not differ statistically between themselves, by Scott-Knott test $(\mathrm{P}<0.05 \%)$. 
Morphoagronomic characterization...

The means for leaf length varied from 4.91 $\mathrm{cm}$ (LAC-012) to $6.90 \mathrm{~cm}$ (LAC-036) among accessions, with formation of two statistically different groups. For the variable leaf width, formation of three groups occurred, ranging from $2.81 \mathrm{~cm}$ (LAC-012) to $5.03 \mathrm{~cm}$ (LAC-025). The relationship between the length and width of the leaf blade points to the shape of the leaf. If the quotient presents a value below 1.00 , the greater the tendency of the leaf to have a "rounded" shape, and as this value increases the foliage tends to have a "lanceolate" shape. Four groups were formed for this variable, with values between $1.32 \mathrm{~cm}$ (LAC025) and $1.87 \mathrm{~cm}$ (LAC-038), i.e., for all accessions, the leaves presented more the lanceolate shape than the rounded. For the characteristic leaf area, there was a variance between $9.59 \mathrm{~mm}^{2}$ (LAC-012) and $22.98 \mathrm{~mm}^{2}$ (LAC-034), with formation of two different groups. According to the literature, cambará leaves are simple, petiolated, and pubescent; present opposing-decussated phyllotaxis, acute and acuminate apex, and serrated edges; they are rough and may cause skin irritation due to the presence of trichomes; and are 5-9-cm long (SHARMA et al., 2007; PASSOS; MEIRA; BARBOSA, 2009). All foliar characteristics observed in the accessions of this study corroborate with the data from the literature.

Concerning crown diameter, there was the formation of two groups with means ranging from $99.00 \mathrm{~cm}$ (LAC-017) to $215.00 \mathrm{~cm}$ (LAC-037). As for plant height, we observed formation of three statistically different groups, accessions LAC-003 $(85.67 \mathrm{~cm})$ and LAC-037 $(214.33 \mathrm{~cm})$ stood out for presenting the smallest and the largest height, respectively. Accessions LAC-040 $(1.08 \mathrm{~cm})$ and LAC-035 $(2.43 \mathrm{~cm})$ presented the lowest and highest value of stem diameter, respectively. Two distinct groups were formed for this variable. For genetic improvement programs, smaller plants are desirable since they occupy less space on the field and respond better to fertilizer application (OSMAN et al., 2011). In native areas, the Lantana forms dense bushes with 2-3 $\mathrm{m}$ in height and spreads its branches over an area of $1 \mathrm{~m}^{2}$ (SHARMA et al., 2007).

For the characteristic growth habit, we observed formation of two groups. The accessions presented mean scores that ranged from 1.33 (LAC002 and LAC-013) to 2.33 (LAC-007), i.e., most accessions presented only $25 \%$ of branches touching the ground. This is an important characteristic in both the maintenance of the collection and for commercial cultivation, as it facilitates crop mechanization and the management of plants.
NASCIMENTO, L. F. A. et al.

There was diversity among the accesses regarding number of flowers in the inflorescence, with formation of four mean groups. Accession LAC-028 (12 flowers) obtained the lowest mean and accession LAC- 027 obtained the highest mean (38 flowers). This characteristic has ornamental importance, as a greater number of flowers gathered in the inflorescences makes them more visually appealing for the trade. In addition, it is known that L. camara presents essential oil in the inflorescences, which makes this accession interesting to studies aimed at the production of essential oil from flowers. Lantana's flowers are a source of nectar for various species of Lepidoptera, which is beneficial for pollinating. An increase in the number of flowers per inflorescence is a differential to attract species to visit the plant more often (SHARMA; RAGHUBANSHI; SINGH, 2005).

The variable color of leaves was heterogeneous for variables Red (adaxial) and Green (adaxial), with formation of four and three statistically distinct groups, respectively. The mixture of RGB colors prints the specific coloration of the leaves sampled. The variation in the percentage of green determines the green shade of the leaves, while a higher percentage of red in the mixture of the three colors shows a clearer shade, and a higher percentage of the blue makes the leaves darker (Table 4).

Regarding qualitative descriptors, we noted that the accessions of $L$. camara did not present phenotypic variability.

The original plants used as source for the cuttings for deployment of the collection, as well as the accessions used in this study showed yellow, orange, or red flowers. However, we observed a change in the color pattern of flowers throughout the days. On the first day of blooming (24h), the flowers presented strong yellow coloring; on the second day (48h), they became orange; and finally, they became reddish after $72 \mathrm{~h}$. This fact corroborates with what was observed by Barros, Rico-Gray and Díaz-Castelazo (2001) in the investigation of the floral strategies (morphology, coloration, rewards) of the species. Great diversity of color can be seen in the varieties of Lantana with flowers that bloom yellow and change to pink, white, or red, for example. The color yellow is a visual clue for pollinating insects, and the color change can be stimulated after pollination (SHARMA; RAGHUBANSHI; SINGH, 2005). All accessions presented thorns along the length of the main stem and branches of the plant. According to the literature, L. camara may or may not present 
thorns as a defense strategy against herbivory (GHISALBERTI, 2000).

Table 4. Sum of colors red, green and blue, and their hexadecimal codes.

\begin{tabular}{|c|c|c|c|c|c|c|c|c|c|c|c|c|c|c|c|}
\hline Accession & $\begin{array}{l}\text { Red } \\
\text { (adaxial }\end{array}$ & & $\begin{array}{l}\text { Green } \\
\text { (adaxial) }\end{array}$ & & $\begin{array}{l}\text { Blue } \\
\text { (adaxial }\end{array}$ & & Color & Code & $\begin{array}{l}\text { Red } \\
\text { (abaxial }\end{array}$ & & $\begin{array}{l}\text { Green } \\
\text { (abaxial) }\end{array}$ & & $\begin{array}{l}\text { Blue } \\
\text { (abaxial }\end{array}$ & Color & Code \\
\hline LAC-001 & 61.83 & $\mathrm{c}$ & 95.50 & $\mathrm{~b}$ & 36.92 & $\mathrm{a}$ & & \# 3E5C25 & 101.17 & $\mathrm{a}$ & 127.38 & $\mathrm{a}$ & 60.13 & $\mathrm{a}$ & \# 657F3C \\
\hline LAC-002 & 61.42 & $\mathrm{c}$ & 93.92 & b & 27.21 & $\mathrm{a}$ & & \# 3D5E1B & 96.50 & $\mathrm{a}$ & 123.08 & a & 58.25 & $\mathrm{a}$ & \# 617B3A \\
\hline LAC-003 & 61.83 & $\mathrm{c}$ & 94.17 & b & 26.75 & $\mathrm{a}$ & & \# 39591B & 95.54 & $\mathrm{a}$ & 125.21 & $\mathrm{a}$ & 57.67 & $\mathrm{a}$ & \# 607D3A \\
\hline LAC-004 & 62.75 & $\mathrm{c}$ & 95.21 & b & 26.46 & $\mathrm{a}$ & & \# 3F5F1A & 99.79 & $\mathrm{a}$ & 128.29 & $\mathrm{a}$ & 61.00 & $\mathrm{a}$ & \# 64803D \\
\hline LAC-007 & 59.54 & $\mathrm{c}$ & 95.83 & b & 26.46 & $\mathrm{a}$ & & \# 3C5D1A & 97.46 & $\mathrm{a}$ & 124.46 & $\mathrm{a}$ & 57.88 & $\mathrm{a}$ & \# 617C3A \\
\hline LAC-011 & 54.17 & d & 88.33 & $\mathrm{c}$ & 27.25 & $\mathrm{a}$ & & \# 36581B & 93.08 & $\mathrm{a}$ & 123.58 & $\mathrm{a}$ & 54.08 & $\mathrm{a}$ & \# 5D7C36 \\
\hline LAC-012 & 74.00 & $\mathrm{a}$ & 104.42 & $\mathrm{a}$ & 25.75 & $\mathrm{a}$ & & \# 47681A & 92.33 & $\mathrm{a}$ & 115.33 & $\mathrm{a}$ & 49.67 & $\mathrm{a}$ & \# 5C7332 \\
\hline LAC-013 & 61.00 & $\mathrm{c}$ & 86.79 & $\mathrm{c}$ & 24.79 & $\mathrm{a}$ & & \# 375719 & 104.46 & $\mathrm{a}$ & 133.25 & $\mathrm{a}$ & 60.33 & $\mathrm{a}$ & \# 68853C \\
\hline LAC-016 & 57.64 & d & 87.91 & $\mathrm{c}$ & 28.31 & $\mathrm{a}$ & & $\# 35$ & 94.00 & $\mathrm{a}$ & 122.00 & $\mathrm{a}$ & 59.69 & $\mathrm{a}$ & $\mathrm{A} 3 \mathrm{C}$ \\
\hline LAC-017 & 60.23 & $\mathrm{c}$ & 92.06 & $\mathrm{c}$ & 31.50 & $\mathrm{a}$ & & \# 395A20 & 95.50 & $\mathrm{a}$ & 124.75 & $\mathrm{a}$ & 59.69 & $\mathrm{a}$ & D3C \\
\hline LAC-018 & 55.08 & d & 95.17 & b & 29.13 & $\mathrm{a}$ & & \# 37581D & 85.00 & $\mathrm{a}$ & 112.46 & $\mathrm{a}$ & 53.13 & $\mathrm{a}$ & \# 557035 \\
\hline LAC-019 & 62.25 & $\mathrm{c}$ & 94.21 & $\mathrm{~b}$ & 28.83 & $\mathrm{a}$ & & \# 3E5E1D & 98.75 & $\mathrm{a}$ & 127.00 & $\mathrm{a}$ & 58.71 & $\mathrm{a}$ & F3B \\
\hline LAC-021 & 65.83 & $b$ & 100.21 & $\mathrm{a}$ & 20.50 & $\mathrm{a}$ & & \# 4261 & 99.75 & $\mathrm{a}$ & 126.63 & $\mathrm{a}$ & 57.13 & $\mathrm{a}$ & E39 \\
\hline LAC-025 & 53.21 & d & 83.75 & $\mathrm{c}$ & 33.00 & $\mathrm{a}$ & & $\# 3550$ & 93.21 & $\mathrm{a}$ & 117.71 & $\mathrm{a}$ & 57.54 & $\mathrm{a}$ & $763 \mathrm{~A}$ \\
\hline LAC-027 & 71.37 & $\mathrm{a}$ & 103.04 & $\mathrm{a}$ & 22.00 & $\mathrm{a}$ & & \# 446616 & 100.21 & $\mathrm{a}$ & 127.25 & $\mathrm{a}$ & 60.38 & $\mathrm{a}$ & $\mathrm{F} 3 \mathrm{C}$ \\
\hline LAC-028 & 55.25 & d & 89.25 & $\mathrm{c}$ & 22.33 & $\mathrm{a}$ & & \# 375616 & 96.58 & $\mathrm{a}$ & 123.75 & $\mathrm{a}$ & 61.33 & $\mathrm{a}$ & 7C3D \\
\hline LAC-034 & 64.54 & $\mathrm{~b}$ & 95.37 & $b$ & 27.58 & $\mathrm{a}$ & & \# 41621C & 99.38 & $\mathrm{a}$ & 127.46 & $\mathrm{a}$ & 58.96 & $\mathrm{a}$ & \# 637F3B \\
\hline LAC-035 & 64.33 & $b$ & 93.79 & $\mathrm{~b}$ & 31.17 & $\mathrm{a}$ & & \# 3D5E1F & 100.08 & $\mathrm{a}$ & 126.21 & a & 62.50 & $\mathrm{a}$ & \# 647E3F \\
\hline LAC-036 & 65.08 & $b$ & 94.33 & $\mathrm{~b}$ & 29.67 & $\mathrm{a}$ & & \# 3D5E1E & 93.33 & $\mathrm{a}$ & 119.46 & $\mathrm{a}$ & 57.38 & $\mathrm{a}$ & \# 5D7739 \\
\hline LAC-037 & 59.56 & $\mathrm{c}$ & 92.13 & $\mathrm{c}$ & 24.06 & $\mathrm{a}$ & & \# 3A5A19 & 103.00 & $\mathrm{a}$ & 133.00 & $\mathrm{a}$ & 56.31 & $\mathrm{a}$ & \# 668538 \\
\hline LAC-038 & 63.50 & $\mathrm{~b}$ & 99.29 & $\mathrm{a}$ & 19.21 & $\mathrm{a}$ & & \# 406313 & 96.04 & $\mathrm{a}$ & 125.83 & $\mathrm{a}$ & 53.42 & $\mathrm{a}$ & \# 607E35 \\
\hline LAC-040 & 62.32 & $\mathrm{c}$ & 94.36 & $\mathrm{~b}$ & 29.39 & $\mathrm{a}$ & & \# 4B6E0Е & 102.01 & $\mathrm{a}$ & 127.60 & $\mathrm{a}$ & 61.46 & $\mathrm{a}$ & \# 66803D \\
\hline CV (\%) & 6.10 & & 4.38 & & 20.59 & & & & 7.07 & & 5.74 & & 8.14 & & \\
\hline
\end{tabular}

Means followed by the same letter in the column do not differ statistically between themselves, by Scott-Knott test $(\mathrm{P}<0.05 \%)$.

The morphological variability observed in this study was already expected, since the accessions were collected from different native populations of cambará in the state of Sergipe, i.e., plants that have not undergone any selection process. The phenotype variation may be influenced by environmental components or genetic differentiation among individuals (SILVA et al., 2017). However, the collection was assembled in a randomized blocks experimental scheme to minimize the environmental effects on the accessions and to point out statistically the occurrence of these effects, if they happened. Therefore, we consider the genetic factor as the main responsible for the phenotypic plasticity found in the accessions characterized in this study.

Differences among the variables plant height and width, leaf length, leaf width and L/W ratio were also observed in Ocimum sp. (BLANK et. al., 2004), Hyptis pectinata (ARRIGONI-BLANK et. al., 2005), Lippia sidoides, and L. gracilis (SANTOS et al., 2016), confirming the great morphological variability that exists among medicinal plants.

In a study conducted with species of the Lantana genus, morphological traits were useful to correctly discriminate three taxa possibly subjected to natural hybridization (L. strigocamara, L. camara synonym; L. depressa var. depressa, and $L$. depressa var. floridana). The results expressed 98, 91 , and $89 \%$ accuracy for discrimination of the mentioned taxa, respectively (MASCHINSKI; SIRKIN; FANT, 2010). According to Goyal and Sharma (2015), morphological traits such as size, shape, and color of the flowers; size and color of the leaves; presence of thorns on the stem; plant height; and branch architecture can be used to recognize the extensive variability found within what they call a Lantana camara L. (sensu lato) complex, formed by about 600 varieties (VED et al., 2018).

The analysis of morphological traits is essential to study variability among BAG accessions. In a study carried out with the Ocimum basilicum species, Egata, Geja and Mengesha (2017) used seven qualitative descriptors and 22 quantitative descriptors to evaluate the variability of 28 accessions. The authors found variability among the accessions and concluded that the study of the morphological variability produces information that may assist in the identification of genetic variations, as well as in the implementation of genetic improvement programs. 
There was significant difference $(\mathrm{p}<0.05)$ among the accessions for all the agronomical variables evaluated (Table 5).

Table 5. Dry mass of leaves, content and yield of the essential oil of Lantana camara from the Active Germplasm Bank of medicinal and aromatic plants of the Federal University of Sergipe.

\begin{tabular}{lllllll}
\hline Accession & \multicolumn{2}{l}{ Mass dryweight $\left(\right.$ g.plant $\left.{ }^{-1}\right)$} & \multicolumn{2}{c}{ Content $(\%)$} & \multicolumn{2}{l}{ Yield $\left(\mathrm{mL}\right.$.plant $\left.{ }^{-1}\right)$} \\
\hline LAC-001 & 191.13 & $\mathrm{c}$ & 0.17 & $\mathrm{c}$ & 0.31 & $\mathrm{~d}$ \\
LAC-002 & 75.61 & $\mathrm{~d}$ & 0.16 & $\mathrm{c}$ & 0.12 & $\mathrm{~d}$ \\
LAC-003 & 252.30 & $\mathrm{c}$ & 0.14 & $\mathrm{~d}$ & 0.34 & $\mathrm{~d}$ \\
LAC-004 & 459.28 & $\mathrm{~b}$ & 0.24 & $\mathrm{~b}$ & 1.14 & $\mathrm{~b}$ \\
LAC-007 & 171.28 & $\mathrm{c}$ & 0.26 & $\mathrm{a}$ & 0.44 & $\mathrm{c}$ \\
LAC-011 & 80.61 & $\mathrm{~d}$ & 0.18 & $\mathrm{c}$ & 0.17 & $\mathrm{~d}$ \\
LAC-012 & 148.78 & $\mathrm{~d}$ & 0.14 & $\mathrm{~d}$ & 0.21 & $\mathrm{~d}$ \\
LAC-013 & 131.78 & $\mathrm{~d}$ & 0.13 & $\mathrm{~d}$ & 0.18 & $\mathrm{~d}$ \\
LAC-016 & 240.44 & $\mathrm{c}$ & 0.23 & $\mathrm{~b}$ & 0.60 & $\mathrm{c}$ \\
LAC-017 & 90.04 & $\mathrm{~d}$ & 0.16 & $\mathrm{c}$ & 0.19 & $\mathrm{~d}$ \\
LAC-018 & 386.83 & $\mathrm{~b}$ & 0.14 & $\mathrm{~d}$ & 0.53 & $\mathrm{c}$ \\
LAC-019 & 175.31 & $\mathrm{c}$ & 0.13 & $\mathrm{~d}$ & 0.24 & $\mathrm{~d}$ \\
LAC-021 & 157.70 & $\mathrm{~d}$ & 0.13 & $\mathrm{~d}$ & 0.21 & $\mathrm{~d}$ \\
LAC-025 & 127.99 & $\mathrm{~d}$ & 0.13 & $\mathrm{~d}$ & 0.17 & $\mathrm{~d}$ \\
LAC-027 & 233.50 & $\mathrm{c}$ & 0.18 & $\mathrm{c}$ & 0.45 & $\mathrm{c}$ \\
LAC-028 & 83.43 & $\mathrm{~d}$ & 0.23 & $\mathrm{~b}$ & 0.17 & $\mathrm{~d}$ \\
LAC-034 & 49.86 & $\mathrm{~d}$ & 0.21 & $\mathrm{~b}$ & 0.10 & $\mathrm{~d}$ \\
LAC-035 & 126.69 & $\mathrm{~d}$ & 0.25 & $\mathrm{a}$ & 0.33 & $\mathrm{~d}$ \\
LAC-036 & 132.25 & $\mathrm{~d}$ & 0.21 & $\mathrm{~b}$ & 0.28 & $\mathrm{~d}$ \\
LAC-037 & 649.04 & $\mathrm{a}$ & 0.25 & $\mathrm{a}$ & 1.55 & $\mathrm{a}$ \\
LAC-038 & 570.51 & $\mathrm{a}$ & 0.21 & $\mathrm{~b}$ & 1.22 & $\mathrm{~b}$ \\
LAC-040 & 266.75 & $\mathrm{c}$ & 0.25 & $\mathrm{a}$ & 0.64 & $\mathrm{c}$ \\
\hline CV & 27.45 & & 8.10 & & 36.73 & \\
\hline Means followed by the same letter in the column do not differ statistically between themselves, by Scott-Knott test $(\mathrm{P}<0.05 \%)$.
\end{tabular}

The production of biomass is an important factor in studies with medicinal plants and the quantification of this production can only be accomplished analyzing the agronomic traits. The essential oil of $L$. camara is the main product of this medicinal species. The yield (amount) and chemical composition (quality) of the essential oil depend on genetic and environmental factors. These factors also determine vegetative characteristics such as plant height, crown diameter, and leaf area, which together influence the productive characteristics.

Regarding the dry mass, four groups were formed, and the accessions LAC-034 (49.86 g.plant ${ }^{-}$ $\left.{ }^{1}\right)$ and LAC-037 (649.04 g.plant ${ }^{-1}$ ) showed the lowest and highest mean production of dry mass, respectively. It is possible to notice that not all accessions with greater plant height, largest crown diameter, or greater leaf area obtained the greatest amount of dry matter. This happens because the production of dry mass from the aerial part is more related to the quantity and size of leaves.

The means for essential oil content of the accessions formed four groups and ranged from $0.13 \%$ (LAC-13, LAC-19, LAC-21, LAC-25) to $0.26 \%$ (LAC-007). We observed a great variation for essential oil content among the accessions and this can be a characteristic targeted by genetic improvement programs. The levels found in this study corroborate with those observed in other studies for the Lantana genus. The essential oils from the aerial parts, extracted by hydrodistillation, present content ranging from 0.01 to $0.7 \%$ (SOUSA; COSTA, 2012).

Mathematically, the yield of essential oil is directly connected to the content of this oil and dry mass produced per plant. In general, the accessions that produced higher dry mass values, also presented greater yield of essential oil. Four statistically distinct groups were formed and accessions LAC034 (0.10 mL.plant $\left.{ }^{-1}\right)$ and LAC-037 (1.55 mL.plant ${ }^{-}$ $\left.{ }^{1}\right)$ presented the lowest and highest yield of essential oil, respectively.

For the multivariate analysis, we used the quantitative morphological descriptors and agronomic descriptors, totaling 18 variables.

The cluster analysis is one of the steps of a study on divergence and aims at pointing out which accessions have greater or lesser similarity (BIANCHINI et al., 2017). The results obtained by the clustering method (Figure 2) highlighted the phenotypic variability found among the accessions. The descriptors defined the formation of six groups. 


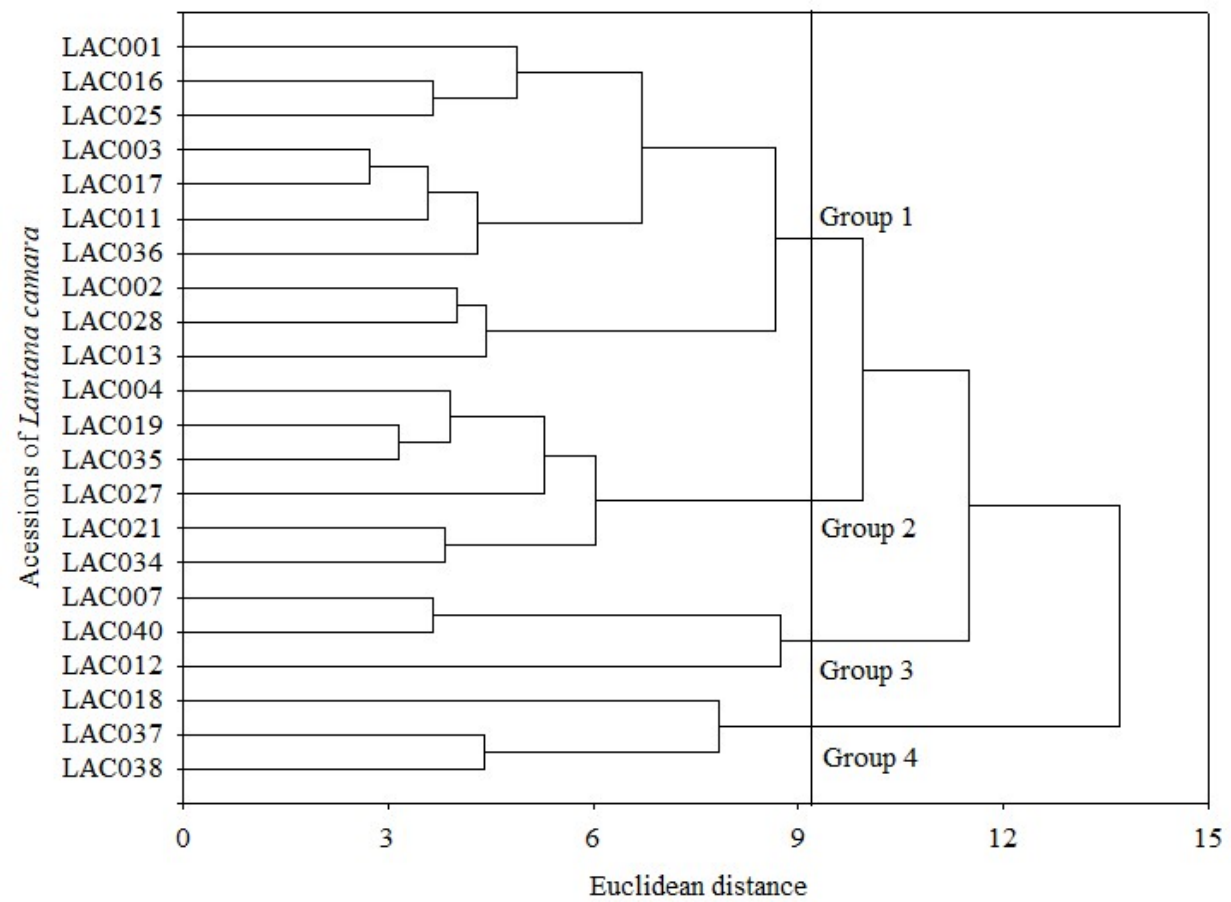

Figure 2. Two-dimensional dendrogram representing the similarity among twenty-two accessions of Lantana camara regarding morphoagronomic variables.

The four groups formed by the phenotypic similarity between the accessions were: Group 1, with 10 accessions: LAC-001, LAC-002, LAC-003, LAC-011, LAC-013, LAC-016, LAC-017, LAC025, LAC-028 and LAC-036; Group 2, with 6 accessions: LAC-004, LAC-019, LAC-021, LAC027, LAC-034 and LAC-035; Group 3, with 3 accessions: LAC-007, LAC-012, and LAC-040; and Group 4, with 3 accessions: LAC-018, LAC-037 and LAC-038.

It is possible to observe that the groups were not formed exclusively by accessions from the same municipality, showing that there was variability including among accessions collected in a same location. The most divergent accessions, phenotypically, were LAC-001 (São Cristóvão) and LAC-038 (Moita Bonita) and the ones with the lowest divergence were LAC-004 (Itaporanga D'ajuda) and LAC-019 (Siriri). In the study carried out by Camelo et al. (2011) with accessions of Lippia alba, the authors noted that the phenotypic differences among them happened regardless of different origins, as observed in this study.

The divergence observed among accessions allows us to explore heterosis through crosses between individuals of different groups. The exploration of heterosis is applied generally in selfpollinated crops, but can also be explored for the development of hybrid cultivars. Hybridization has been widely used with the goal of gathering, in a single individual, traits that exist in different genotypes, improving the selection of the optimal genotype, with high yield and production quality, for example (FREIRE et al., 2007).

The principal component analysis (PCA) explained $45.85 \%$ of the total phenotypic variability in two main components (Figure 3). The primary main component represented $28.23 \%$ of the total variance and was negatively correlated with leaf width $(r=-0.93)$ and leaf area $(r=-0.87)$, and positively with leaf length/width $(\mathrm{r}=0.76)$, and $\mathrm{G}$ (adaxial) ( $\mathrm{r}=-0.72)$. The secondary main component represented $17.62 \%$ of the total variance and was positively correlated with the variables essential oil yield $(r=0.83)$, dry mass $(r=0.89)$, plant height $(\mathrm{r}=0.79)$ and plant width $(\mathrm{r}=0.79)$. There was no strong negative correlation to the secondary main component. The use of principal component multivariate analysis allows the identification of the more informative morphoagronomic markers for the studied species, thus, reducing the time and optimizing the analysis of characterization in future studies (ALVES et al., 2017).

L. camara is a species with high phenotypic plasticity (MUNGI et al., 2018) and this is a crucial point for the improvement of the species. Due to the high natural diversity, conventional improvement approaches can be adopted, especially because they are relatively cheaper methods (SARROU et al., 2017). 


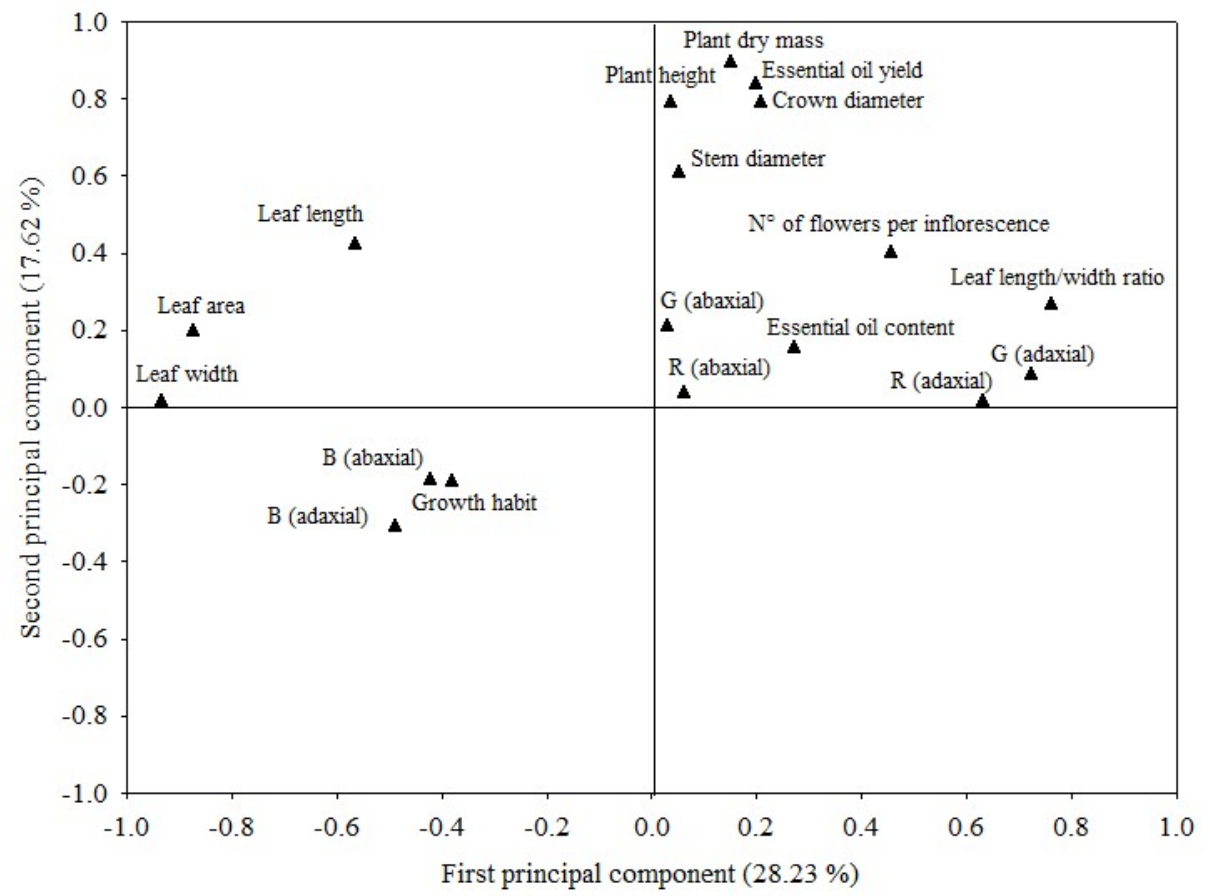

Figure 2. Distribution of the morphoagronomic variables of Lantana camara accessions concerning the two main components through principal component analysis (PCA).

Variables: Leaf length (LL), leaf width (LW), leaf length/width ratio (L/W), leaf area (LA); crown diameter (DCr); plant height (PH), stem diameter (DSt), growth habit (GH), number of flowers per inflorescence (NFI), Red (adaxial), Red (abaxial), Green (adaxial), Green (abaxial), Blue (adaxial), Blue (abaxial), plant dry mass (DM), essential oil content (EOC), essential oil yield (EOY).

This study demonstrated that there is significant morphoagronomic variability in important traits among the accessions, enabling the improvement of crop productivity through selection and genetic improvement. The expansion of genetic variability can be obtained by hybridization between the more divergent accessions (LAC-001 and LAC038) or between the accessions that presented higher means for the agronomic traits (LAC-027 and LAC037).

\section{ACKNOWLEDGMENTS}

This study was financed in part by the Conselho Nacional de Desenvolvimento Científico e Tecnológico - Brasil (CNPq), the Fundação de Apoio à Pesquisa e a Inovação Tecnológica do Estado de Sergipe (Fapitec/SE) - Brasil, the Coordenação de Aperfeiçoamento de Pessoal de Nível Superior - Brasil (CAPES - Finance Code 001), the Financiadora de Estudos e Projetos - Brasil (FINEP), and Embrapa Tabuleiros Costeiros.

RESUMO: A espécie aromática e medicinal Lantana camara, é um arbusto muito usado para ornamentação. Devido à sua condição de planta invasora em ambientes naturais, sofre com tentativas de erradicação constantes, o que ocasiona erosão genética da espécie. Para contornar essa problemática, uma amostra da variabilidade genética da L. camara está sendo conservada no Banco Ativo de Germoplasma (BAG) de Plantas Medicinais e Aromáticas da Universidade Federal de Sergipe (UFS). Assim, objetivou-se com o presente trabalho avaliar morfoagronomicamente 22 acessos de L. camara, coletados em 15 municípios do estado de Sergipe. Para caracterização morfoagronômica, variáveis morfológicas e agronômicas foram analisadas. Observou-se variabilidade fenotípica entre os acessos da coleção de $L$. camara para a maioria das características morfológicas quantitivas e agronômicas. A média para comprimento de folha variou de 4,91 e $6,90 \mathrm{~cm}$; largura de folha de 2,81 a 5,03 cm; relação comprimento/largura de 1,32 a 1,87; área folia de 9,59 a $22,98 \mathrm{~mm}^{2}$; diâmetro da copa de 99,00 a 215,00 cm; altura de planta de 85,67 a 214,33 cm; diâmetro do caule de 1,08 a 2,43 cm; A maioria dos acessos apresentou porte ereto. O número médio de flores por inflorescências variou de 12 a 38. Para as características agronômicas observou-se que a massa seca variou de 49,86 a 649,04 g.planta ${ }^{-1}$. A média para teor de óleo essencial variou de 0,13 a $0,26 \%$ e o rendimento entre 0,10 a 1,55 
mL.planta ${ }^{-1}$. Os acessos mais divergentes fenotipicamente foram LAC-001 (São Cristóvão) e LAC-038 (Moita Bonita) e os que apresentaram a menor divergência foram LAC-004 (Itaporanga D'ajuda) e LAC-019 (Siriri). Dessa forma, nota-se que as variáveis foram eficientes para diferenciar os acessos e sugerem a existência de variabilidade genética entre eles.

PALAVRAS-CHAVE: Verbenaceae. Planta aromática e medicinal. Banco Ativo de Germoplasma. Descritores. Diversidade.

\section{REFERENCES}

ALVES, R. P.; BLANK, A. F.; OLIVEIRA, A. M. S.; SANTANA, A. D. D.; PINTO, V. S; ANDRADE, T. M. Morpho-agronomic characterization of sweet potato germplasm. Horticultura Brasileira, Brasília, v. 35, n. 5, p. 525-541, 2017. http://dx.doi.org/10.1590/S0102-053620170410

ARRIGONI-BLANK, M. F.; SILVA-MANN; CAMPOS, D. A.; SILVA, P. A.; ANTONIOLLI, A. R.; CAETANO, L. C.; SANTANA, A. E. G.; BLANK, A. F. Morphological, agronomical and pharmacological charecterization of Hyptis pectinata (L) Poit germolplasm. Revista Brasileira de Farmacognosia, São Paulo, v.15, n.4, p.298-303, 2005. http://dx.doi.org/10.1590/S0102-695X2005000400007

BARROS, M. G.; RICO-GRAY, V.; DÍAZ-CASTELAZO, C. Sincronia de floração entre Lantana camara L. (Verbenaceae) e Psittacanthus calyculatus (DC.) G. Don (Loranthaceae) ocorrentes em dunas de La Mancha, Veracruz, México. Acta Botanica Mexicana, Brasília, v.57, p.1-14, 2001. Avaliable in:

$<$ https://www.researchgate.net/publication/28291435_Sincronia_de_floracao_entre_Lantana_camara_L_Verbe naceae_e_Psittacanthus_calyculatus_DC_G_Don_Loranthaceae_ocorrentes_nas_dunas_de_La_Mancha_Verac ruz_Mexico>. Acess in: 30 jan. 2019. https://doi.org/10.21829/abm57.2001.880

BIANCHINI, F. G.; BALBI, R. V.; PIO, R.; BRUZI, A. T.; SILVA, D. F. Parents choice and genetic divergence between cambuci fruit tree accessions. Crop Breeding and Applied Biotechnology, Londrina, v.17, p. 214-220, 2017. http://dx.doi.org/10.1590/1984- 70332017v17n3a33

BLANK, A. F.; CARVALHO FILHO, J. L. S.; SANTOS NETO, A. L.; ALVES, P. B.; ARRIGONI-BLANK, M. F.; SILVA-MANN, R.; MENDONÇA, M.C. Caracterização morfológica e agronômica dos acessos de manjericão e alfavaca. Horticultura Brasileira, Brasília, v.22, n.1, p.113-116, 2004.

http://dx.doi.org/10.1590/S0102-05362004000100024

BLANK, A. F. Transformação de recursos genéticos de plantas aromáticas nativas em riqueza: o potencial do alecrim-de-tabuleiro (Lippia gracilis). Horticultura Brasileira, Brasília, v. 31, n. 3, p. 512, 2013. http://dx.doi.org/10.1590/S0102-05362013000300029

CAMÊLO, L. C. A.; BLANK, A. F.; EHLERT, P. A. D.; CARVALHO, C. R. D.; ARRIGONI-BLANK, M. F.; MATTOS, J. Caracterização morfológica e agronômica de acessos de erva cidreira-brasileira [Lippia alba (Mill.) N. E. Br.]. Scientia Plena, São Cristóvão, v. 7, n. 5, p. 1-8, 2011. Disponível em: $<$ https://www.scientiaplena.org.br/sp/article/view/87>. Acesso em: 30 jan. 2019.

DENG, Z.; WILSON, S. B.; YING, X.; CZARNECKI II, D. M. Infertile Lantana camara Cultivars UF-1011-2 and UF-1013A-2A. HortScience, Alexandria, v. 52, n. 4, p. 652-657, 2017. Avaliable in: $<$ http://hortsci.ashspublications.org/content/52/4/652.extract>. Acesso em: 30 jan. 2019. https://doi.org/10.21273/HORTSCI11840-17

DOS SANTOS, R. C.; DE MELO, A. A.; CHAGAS, E. A.; FERNÁNDEZ, I. M.; TAKAHASHI, A.; FERRAZ, V. P. Influence of diurnal variation in the chemical composition and bioactivities of the essential oil from fresh and dried leaves of Lantana camara. Journal of Essential Oil Research, London, p. 1-7, 2019. https://doi.org/10.1080/10412905.2018.1555102 
EGATA, D. F.; GEJA, W.; MENGESHA, B. Agronomic and bio-chemical variability of ethiopian sweet basil (Ocimum basilicum L.) accessions. Academic Research Journal of Agricultural Science and Research, Delta, v. 5, n. 7, p. 489-508, 2017. http://dx.doi.org/10.14662/ARJASR2017.078

FREIRE, E. C.; LIMA, E. F.; ANDRADE, F. P.; MILANI, M; NÓBREGA, M. B. M. Melhoramento Genético. In: AZEVEDO, D. M. P.; BELTRÃO, N. E. M. (Ed.). O Agronegócio da mamona no Brasil. 2. ed. Brasília: Embrapa Informação Tecnológica, 2007. p. 169-194.

GHISALBERTI, E. L. Lantana camara L. (Verbenaceae). Fitoterapia, Milano, v. 71, n. 5, p. 467-486, 2000. https://doi.org/10.1016/S0367-326X(00)00202-1

GOYAL, N.; SHARMA, G. P. Lantana camara L. (sensu lato): an enigmatic complex. NeoBiota, Sophia, v. 25, p. 15-26, 2015. http://dx.doi.org/10.3897/neobiota.25.8205

JAGTAP, S.; KATARIYA, T.; PHARATE, M.; NAJAN, A. A review on medicinal properties of Lantana camara Linn. World Journal of Pharmacy and Pharmaceutical Sciences, Sophia, v. 7, n. 9, p. 288-294, 2018. https://doi.org/10.20959/wjpps20189-12195

JANSKY, S. H.; DAWSON, J.; SPOONER, D. M. How do we address the disconnect between genetic and morphological diversity in germplasm collections? American Journal of Botany, Baltimore, v. 102, n. 8, p. 1213-1215, 2015. http://dx.doi.org/10.3732/ajb.1500203

MASCHINSKI, J.; SIRKIN, E.; FANT, J. Using genetic and morphological analysis to distinguish endangered taxa from their hybrids with the cultivated exotic pest plant Lantana strigocamara (syn: Lantana camara).

Conservation Genetics, Dordrecht, v 11, p. 1607-1621, 2010. http://dx.doi.org/10.1007/s10592-009-0035-6

MEDEIROS, L. B. M.; ROCHA, M. S.; LIMA, S. G.; SOUSA JÚNIOR, G. R.; CITÓ, A. G. L.; SILVA, D.; LOPES, J. A. D.; MOURA, D. J.; SAFFI, J.; MOBIN, M.; COSTA, J. G. M. Chemical constituents and evaluation of cytotoxic and antifungal activity of Lantana camara essential oils. Revista Brasileira de Farmacognosia, São Paulo, v. 22, n. 6, p. 1259-1267, 2012. http://dx.doi.org/10.1590/S0102695X2012005000098

MUNGI, N. A.; COOPS, N. C.; RAMESH, K.; RAWAT, G. S. How global climate change and regional disturbance can expand the invasion risk? Case study of Lantana camara invasion in the Himalaya. Biological Invasions, Dordrecht, v. 20, n. 7, p. 1849-1863, 2018. http://dx.doi.org/10.1007/s10530-018-1666-7

NIZIO, D. A. C.; BLANK, A. F.; SAMPAIO, T. S.; BRITO, F. A.; ANDRADE, T. M.; ARRIGONI-BLANK, M. F.; MARIA, A. N. Distillation methods affect the chemical composition of Varronia curassavica Jacq. essential oil? Bioscience Journal, Uberlândia, v. 34, n. 3, p. 629-639, 2018. http://dx.doi.org/10.14393/BJv34n3a2018-39372

OSMAN, M.; GOLAM, F.; SABERI, S.; MAJID, N. A.; NAGOOR, N. H.; ZULQARNAIN, M. Morphoagronomic analysis of three roselle (Hibiscus sabdariffa L.) mutants in tropical Malaysia. Australian Journal of Crop Science, Lismore, v. 5, n. 10, p. 1150-1156, 2011. Avaliable in:

$<$ http://www.cropj.com/golam_5_10_2011_1150_1156.pdf >. Acess in: 30 jan. 2019.

PASSOS, J. L.; MEIRA, R. M. S. A.; BARBOSA, L. C. A. Foliar anatomy of the species Lantana camara and L. radula (verbenaceae). Planta Daninha, Viçosa, v. 27, n. 4, p. 689-700, 2009.

http://dx.doi.org/10.1590/S0100-83582009000400007

PRASAD, A.; RATMAN, J.; SANKARAN, M. Rainfall and removal method influence eradication success for Lantana camara. Biological Invasions, Dordrecht, v. 20, n. 12, p. 3399-3407, 2018.

https://doi.org/10.1007/s10530-018-1785-1 
SANTANA. A. D. D.; BLANK, A. F.; ARRIGONI-BLANK, M. F.; ANDRADE, T. M.; ALVES, M. F.; MELO, J. O.; ALVES, P. B. Phenotypic and genotypic characterization of basil hybrids and cultivars.

Biosciense Journal, Uberlândia, v. 34, n. 5, p. 1167-1177, 2018. http://dx.doi.org/10.14393/BJ-v34n5a201839445

SANTOS, R. C.; FILHO, A. A. M.; CHAGAS, E. A.; TAKAHASHI, J. A.; FERRAZ, V. P.; FERNÁNDEZ, I. M.; RIBEIRO, P. R. E.; MELO, A. C. G. R.; HOLANDA, L. C. Chemical composition, antimicrobial and antiacetylcholinesterase activities of essential oil from Lantana camara (Verbenaceae) flowers. Journal of Medicinal Plants Research, Lagos, v. 9, n.35, p. 922- 928, 2015.

http://dx.doi.org/201510.5897/JMPR2015.5919

SANTOS, C. P.; PINHEIRO, J. B.; ZUCCHI, M. I.; BAJAY, M. M.; CAMPOS, J. B.; ARRIGONI-BLANK, M. F.; PINTO J. A. O.; BLANK, A. F. Genetic diversity of Lippia sidoides Cham. and L. gracilis Schauer germplasm. Genetics and Molecular Research, Ribeirão Preto, v. 15, n. 3, p. 1-22, 2016.

http://dx.doi.org/10.4238/gmr.15037781

SARROU, E.; TSIVELIKA, N.; CHATZOPOULOU, P.; TSAKALIDIS, G.; MENEXES, G.; MAVROMATIS, A. Conventional breeding of Greek oregano (Origanum vulgare ssp. hirtum) and development of improved cultivars for yield potential and essential oil quality. Euphytica, Wageningen, v. 213, n. 104, p. 1-16, 2017. http://dx.doi.org/10.1007/s10681-017-1889-1

SHARMA, G. P.; RAGHUBANSHI, A. S.; SINGH, J. S. Lantana invasion: an overview. Weed Biology and Management, Carlton, v. 5, p.157-165, 2005. https://doi.org/10.1111/j.1445-6664.2005.00178.x

SHARMA, O. P., SHARMA, S., PATTABHI, V., MAHATO, S. B., SHARMA, P. D. A review of the hepatotoxic plant Lantana camara. Critical Reviews in Toxicology, Boca Raton, v. 37, n. 4, p. 313-352, 2007. http://dx.doi.org/10.1080/10408440601177863

SILVA, A. V. S.; AMORIM, J. A. E.; VITÓRIA, M. F.; LEDO, A. D. S.; RABBANI, A. R. C. Characterization of trees, fruits and genetic diversity in natural populations of mangaba. Ciência e Agrotecnologia, Lavras, v. 41, n. 3, p. 255-262, 2017. http://dx.doi.org/10.1590/1413-70542017413048416

SOUSA, E. O.; COSTA, J. G. M. Genus Lantana: chemical aspects and biological activities. Revista Brasileira de Farmacognosia, São Paulo, v. 22, n. 5, p. 1155-1180, 2012. http://dx.doi.org/10.1590/S0102695X2012005000058

SOUSA, E. O.; ROCHAC, J. B. T.; BARROS, L. M.; BARROSA, A. R. C.; COSTA, J. G. M. Phytochemical characterization and in vitro antioxidant properties of Lantana camara $\mathrm{L}$. and Lantana montevidensis Briq. Industrial Crops and Products, Amsterdam, v. 43, p. 517-522, 2013. http://dx.doi.org/10.1016/j.indcrop.2012.07.058

VED, A.; ARSI, T.; PRAKASH, O.; GUPTA, A. A review on phytochemistry and pharmacological activity of Lantana camara Linn. International Journal of Pharmaceutical Sciences and Research, Panchkula, v. 9, n. 1, p. 37-43, 2018. http://dx.doi.org/10.13040/IJSR.0975-8232 